corresponding with the top of the candle), during the time it takes to cool, a tendency of the heavy ingredient to fall might cause this difference; and, further, by boiling some stearic acid with two per cent. of linely powdered arsenious acid for two hours, and then allowing the fat to pass a filter kept hot, this fat was found to contain a mere trace of arsenious acid, not more than one grain to a pound; the rest remained on the filter. This fact is, to some extent, important, since although the average quautity added to a given weight of fat may, perhaps, not be injurious, still, as its uniform diffinsion through the mass depends solely on the care of the workmen, not on the solvent quality of the fat, one parcel of candles may contain so large a proportion of this substance, as to make it dangerous to use them, a contingency which the use of this substance to any extent, however small, it is impossible to guard against, and ought to be a strong objection to its use as an article of consumption.

Mr. Phillips and Mr. G. Bird bore their testimony to the accuracy of Mr. Everitt's experiments.

A desultory discussion followed, as to the course the Society ought to pursue in the matter, which determined eventually in leaving the affair to the Committee, whose report on the subject is anxiously looked for.

Medical Sochety of Londox, Nov, 20th.The proceedings of the Society this evening, again, are blank in the annals of reporting. The proceedings were exclusively those of the internal business of the Society, as may be judged from the following notice in the book for entering the names of members, Sc.:- "No visitors or reporters admitted this evening!"

\section{MR. MILLER ON EMBRYOLOGY.}

\section{To the Editor of The LanceT.}

SIR :-I beg to return you, as well as to the Editors of the other weekly medical journals, my grateful thanks, for the insertion of my paper on Human Embryology. I observe in the same number of your Journal, a report of a late meeting of the Academy of Sciences of Paris, in which the discovery of a vesicula umbilicalis in the kangaroo is announced by Mr. Owen.

Having traversed the same grounds at M. Coste and Mr. Owen, and dissected not only the embryos of kangaroos, but of most of the herbivorous and carnivorous animals, the preparations of which are in my possess sion, and have been seen by a large number of the profession in this kingdom, I now call on M. Coste and Mr. Owen to determine, from preparations made by themselves, the following points :-

1st. Where does the duct, from the vesicula umbilicalis in the kangaroo, and in herbivorous and carnivorous animals, terminate in the intestinal canal ?

2nd. Where do the omphalo-mesenteric artery and vein commence and terminate in both classes of auimals?

I shall give them three weeks from this time to answer these questions, and should they fail to come forward, I shall then do so, and supply you and the other journals with engravings of my dissections.

This is only a small part of my researches on comparative and human embryology, all of which I shall shortly publish in an original work; but as many medical gentlemen have urged me to explain my views on the anatomy and physiology of the placenta, and on the prevention of uterine hemorrhage, I shall comply with their request as early as possible. I am, Sir, your obedient servant, John Miller, Mechanic. 3, Theobald's-road, Nov. 20, 1837.

\section{DR. DICKSON AND DR. JOHNSON.}

\section{To the Editor of THE LAncet.}

SIR :-When Dr. James Johnson in his " review" of my recent work on medicine, travelled out of the path of justifiable criticism, to accuse me-falsely as I have proved-of depleting my patients' purses, was he not guilty of gross and illiberal personality? When he seized, moreover, upon a passing remark in a foot-note to one of my page;, mentioning the number of patients treated by me in a given time, by a method fully cred fuirly stuted, and thereupon founded against me a charge of quackery (!) could he be actuated by any other motive than a feeling of personal spleen or hostility? The simple expression of my want of faith in the stethoscope, as an instrument of diagnosis, affords $\mathrm{my}$ critic a fresh opportunity of gratifying his vituperative disposition. Disingenuously suppressing my explanation that the indications obtained through its means were too often neutralised by the alarm of the patient during its application, he fastens upon me a charge of "profound ignorance and inveterate prejudice?" Yet, in a recent number of The Lancet, I find this very $D r$. James Johnson expressing himself, with re gard to the stethoscope, in the following manner, when speaking of the mistreatment of heart diseases-the subject which called 
forth my own opinion of its worthlessuess: - It was a common error of young practitioners to consider the heart as organically diseased when its function only was nuch interfered with-and this error had become more general, he was sorry to say, since the stethoscope came into use." Again, having made me commit the palpable absurdity of saying that "ulcers, abscesses, \&c. were all remittent fevers!"'instead of quoting my own expression, which is, "developments in the course of remittent fover," he has the presumption to accuse me of "madness with a method in it;" and he winds up his tissue of abuse by a statement-false, as my bookseller cun testify - accusing me of gratuitously distributing my publication among my private patients ; and that to the amount of three thousand copies annually! Now, I ask my critic,-I ask you, Mr. Editor, as a gentleman and a journalist, is this criticism? or is it gross personal insult based upon literary misrepresentation and dishonesty?

I have only in conclusion to notice Dr. Johnson's statement of his having received an anonymous letter with the Cheltenham post mark. Dr. Juhnson finds it suitable for his purpose to insinuate that $I$ am the author of that letter; but to those who know my nature and my character I do not require, at this hour, to rebut such an insinuation with my flat and indignant contradiction. *****

With Dr. Johnson I never had a quarrel previous to his published attack upon me. To this hour I am ignorant of his person. Had I been equally unacquainted with his writings it would have been betier for some of my earlier patients. But had he not attacked my private character, I should have left the proofs of the destructive tendency of his lucubrations to time, which, sooner or later, awards to every man his proper appreciation as a writer. I am, Sir, your most obedient servant,

\section{Cheltenham, Nov. 13, 1837.}

\section{S. Dickson.}

[We have thought it right to omit more than half of Dr. Diclson's letter. The portion now inserted must close the correspondence on the disagreeable subject to which it relates.-ED. L.]

\section{MR. HUNT ON ARSENICAL CANDLES.}

To the Editor of THe Lancer.

SIR:-Perceiving, from the report of the proceedings of the IVestminster Medical Society, which appears in THE LANCLT of the $4 \mathrm{th}$ ult., that the important question of the injurious tendency, or otberwise, of the use of arsenic in the composition of candles, was brought before its members, and a ques- tion raised as to the state in which the arsenic would be after combustion, 1 trouble you with a few remarks, the result of a great number of experiments, proving, most conclusively, that Arsincous $A_{C I D}$ or, as it is commonly called, White Oxide of A risenic, is thrown into the air, in a finely divided state, by the burning of the arsenuretted, or, -as they may with propriety be called, - Corpse-candles.

Although carbonaccous fluxes are nsed for reducing white arsenic to a mettllic form, it will be applarent, when we remenber the action of gas in a natant state, on the oxides of this metal, that the reduction is entirely prevented, in this instance, from the deoxidation of the arsenic, by the carburetted-hydrogen formed during the decomposition of the stearine, in the capillary vessels of the wick, and their cousequent combination in the form of arsenio-carburetted hydrogen.

Decomposition is argain effected, during the process of combustion; the carburetted hydrogen forming, with the oxygen of the air, carbonic acid and water, whilst some carbon is set free; and the liberated arsenic is again converted into its oxide.

This may be convincingly shown, by holding over the flame of one of these candles, a glass tube, at an angle of thirty degrees. Carbonaceous matter will be seen to $\hat{f}_{y}$ off, and be deposited around the upper orifice of tube. Selow this, a crust of the white oxide of arsenic will be formed, and, at the point on which the flame impinges, a little metallic arsenic will present itself, which, as the tube becomes heated, sublimes, and is also converted into arsenious acid.

By this easy experiment, the quantity of arsenic used in the composition of the candle, may be iscertained with considerable precision. By closing the ends of the tube, the carbonaceous matter may be used as the deoxidizing agent; and on applying the heat of a spirit lamp, the whole of the pure metal can be sublimed to any convenient part of the glass.

A short period since, having occasion to well light a large apartment, I uscd some spermaceti candles, rrcommended to me for the purpose. During the evening the air of the room became exceedingly oppres. sive, and several persons were distressed with an irritating congh. Suspecting the candles, I submitted them to analysis.

One of them yielded me $160 \mathrm{cubic}$ inches of arsenio-carburetted hydrogen gas, from which I obtained 27 grains of arsenions acid.

Surely the advantages of a good appearance are not so great as to warrant a continuance of this evil practice, by which a very useful article is converted into a deadly and insiduous destroyer. I have the honour to be, Sir, your's $3 \mathrm{c}$.,

London, Nor. 5, 1837. 